\title{
Purification and Characterization of Nitrate Reductase (NAR) from Pseudomonas sp. SH7 Isolate
}

\section{تنقية وتوصيف انزيم Nitrate Reductase (NAR) المنتج من بكتيريا Pseudomonas SH7 العزلة Sp.}

\author{
Shaymaa H. Al-Rajhi Majed H. Al-Gelawi Ghazi M. Aziz \\ Biotechnology Dept., College of Science, Al-Nahrain University \\ *Biotechnology Dept., College of Science, Baghdad University
}

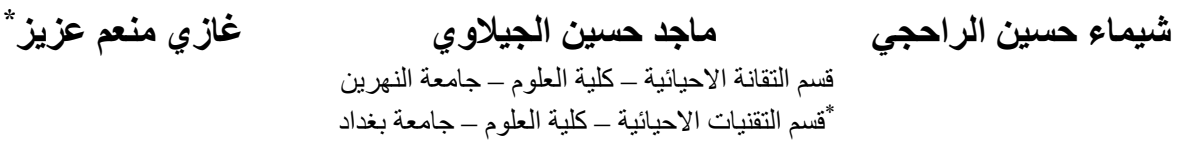

Abstract

Gixty five soil samples and fifteen water samples were collected from 2 different places in which previously explosions were occurred in Iraq. Seven isolates showed ability to utilize $0.1 \mathrm{mM}$ trinitrotoluene (TNT) and/or $0.2 \mathrm{mM}$ glycerol trinitrate (GTN) as a sole carbon and nitrogen source and one of these isolates showed the highest nitrate reduction which was classified and coded as Pseudomonas sp. SH7. The highest nitrate reductase activity extracted by sonication while optimum conditions for enzyme production in minimal media pH 7 containing $0.25 \mathrm{mM}$ GTN at $35^{\circ} \mathrm{C}$ for 3 days under aerobic condition. Nitrate reductase was purified by $40-60 \%$ ammonium sulphate, ion exchange and gel filtration. Nitrate reductase molecular weight determined by SDS-PAGE was $115 \mathrm{kD}$. The characterization of purified enzyme activity and stability was higher at a pH between 6.5-7.5 and. Maximum activity was at $35^{\circ} \mathrm{C}$ and stable at $30-40^{\circ} \mathrm{C}$ for $15 \mathrm{~min}$., while for heat sensitivity $100 \%$ activity observed at $45^{\circ} \mathrm{C}$ for $20 \mathrm{~min}$. Treatment with $200 \mu \mathrm{M}$ azide and $500 \mu \mathrm{M}$ cyanide inhibited the activity by 76 and $91 \%$ respectively.

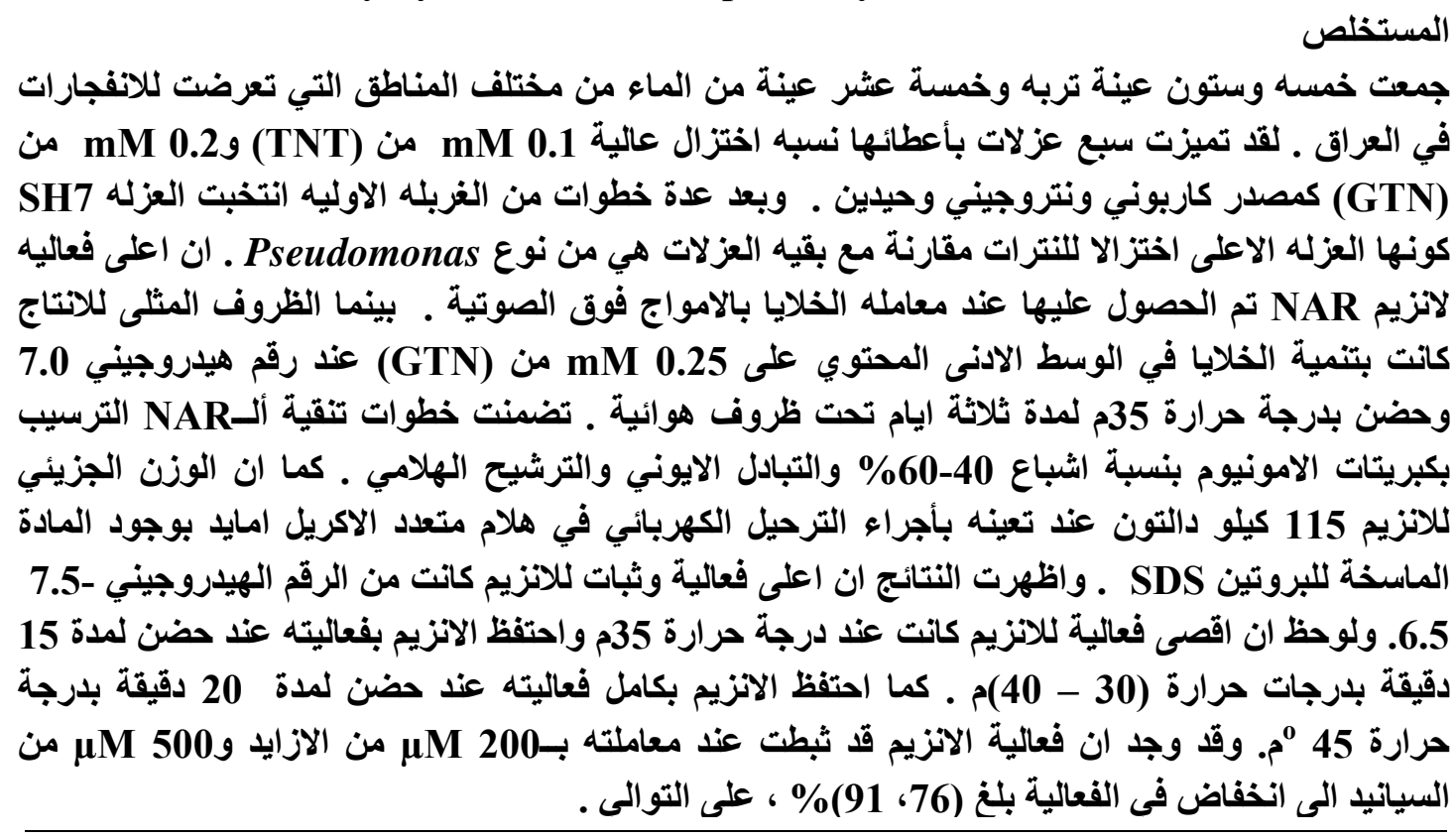

Key words: TNT, GTN, Pseudomonas, Nitrate reductase, Purification. 


\section{Introduction}

Life on this planet is based on the continuous cycling of elements. In the recent years the massive mobilization of natural resources and the industrial synthesis of chemicals have generated a number of environmental problems as a consequence of the limited incorporation of natural and synthesized molecules into ongoing biological cycles. This is particularly true for xenobiotic compounds, which exhibit structural elements or substituents that are rarely found in natural products. Nitroaromatic compounds are xenobiotics that have found multiple applications in the synthesis of foams, pharmaceuticals, pesticides, and explosive. These compounds are toxic, recalcitrant and degraded relatively slowly in the environment by the microorganisms [1].

Nitrate reductases can be performed with three different types: the utilization of nitrate as a nitrogen source for growth (nitrate assimilation), the generation of metabolic energy by using nitrate as a terminal electron acceptor (nitrate respiration), and the dissipation of excess reducing power for redox balancing (nitrate dissimilation). Fourth type of nitrate reductases catalyze the two-electron reduction of nitrate to nitrite was the eukaryotic assimilatory nitrate reductases while the other three distinct bacterial enzymes, comprising the cytoplasmic assimilatory (Nas), membrane-bound respiratory (Nar), and periplasmic dissimilatory (Nap) nitrate reductases. All eukaryotic and bacterial nitrate reductases contain a molybdenum cofactor at their active sites. The basic structure of the eukaryotic cofactor is molybdopterin, a 6-alkyl pterin derivative with a phosphorylated $\mathrm{C} 4$ chain with two thiol groups binding the Mo atom [2].

Nitrate-reducing and true denitrifying bacteria have been shown to harbor either the membrane-bound or the preiplasmic nitrate reductase or both types of reductases. A study focusing on the fluorescent Pseudomonads community showed that $56 \%$ of the isolated strains had nar gen only, $51 \%$ had the nap gene and $15.5 \%$ possessed both nitrate reductase genes [3].

Enzyme application in biotechnology and environmental fields requires a highly purified nitrate reductase with maximum specific activity. Thus, isolate specific strain that had efficient nitrate reductase. Studied the optimization, purification and characterization of nitrate redustase produced from Pseudomomas sp. SH7 isolate.

\section{Materials and Methods}

Sampling: Soil and water from different places in which previously explosions were occurred from (Baghdad, Najaf, Karbala, Basra, Waset, Mousel and Al-Anbar). Two or three tablespoons of soil and $5 \mathrm{ml}$ of water were collected from each locations. Transported in sterile bags, then the samples were stored at $4^{\circ} \mathrm{C}$ until use.

Isolation and Identification: Samples were identified as the criteria of Bergey's Manual of Systematic Bacteriology [4].

Preparation of Cell Extract: Culture of Pseudomonas isolate $\mathrm{SH} 7$ was grown on minimal media (composed of the following $(\mathrm{g} / \mathrm{L}): \mathrm{KH}_{2} \mathrm{PO}_{4} ; 3, \mathrm{MgSO}_{4} .7 \mathrm{H}_{2} \mathrm{O} ; 0.12$, $\mathrm{K}_{2} \mathrm{HPO}_{4} ; 1, \mathrm{NaCl} ; 0.5$ and $1 \mathrm{ml}$ of trace element solution which contained the following $\mathrm{CuSO}_{4} \cdot 5 \mathrm{H}_{2} \mathrm{O} ; 0.06, \mathrm{MnCl}_{2} \cdot 4 \mathrm{H}_{2} \mathrm{O} ; 0.03, \mathrm{ZnSO}_{4} \cdot 7 \mathrm{H}_{2} \mathrm{O} ; 0.31, \mathrm{CoCl}_{2} \cdot 6 \mathrm{H}_{2} \mathrm{O}$; 
$\left.\mathrm{Na}_{2} \mathrm{MoO}_{4} \cdot 2 \mathrm{H}_{2} \mathrm{O} ; 0.03, \mathrm{H}_{3} \mathrm{BO}_{3} ; 0.57, \mathrm{FeCl}_{3} \cdot 6 \mathrm{H}_{2} \mathrm{O} ; 0.24\right)$ containing $0.2 \mathrm{mM}$ GTN at $35^{\circ} \mathrm{C}$ for 3 days, then harvested by centrifugation at $6000 \mathrm{rpm}$ for $20 \mathrm{~min}$., washed, and re-suspended in $0.1 \mathrm{M}$ phosphate buffer. Cells were disrupted by three different methods one of them was sonication for $15 \mathrm{~min}$ at $4^{\circ} \mathrm{C}$ using $20 \mathrm{KHz}$. Residual whole cells and cell membrane fragments were removed by centrifugation 6000rpm for 20 min. The other method was done by adding SDS to the cell suspension with a final concentration of $1 \%$ and the mixture was incubated in shaker water bath at $37^{\circ} \mathrm{C}$ for $30 \mathrm{~min}$. Samples were taken from the mixture, centrifuged at $6000 \mathrm{rpm}$ at $4^{\circ} \mathrm{C}$ for 20 min. While the third method was freezing and thawing in which a $20-\mathrm{ml}$ amount of the cell suspension was placed in a $100-\mathrm{ml}$ container and stored at $-23^{\circ} \mathrm{C}$ until completely frozen. The sample was then placed at $37^{\circ} \mathrm{C}$ until completely thawed. The complete cycle was repeated 5 times with a total elapsed time of 2 to $4 \mathrm{hr}$. Cell suspension from the three methods were centrifuged at $6000 \mathrm{rpm}$ for $20 \mathrm{~min}$. The resulting supernatant was used as the starting point to establish nitrate reductase activity in crude cell extracts.

Assay of nitrate reductase: Nitrate reductase activity was assayed with reduced BNADH as an electron donor [5].

Protein determinations: Protein was performed by Bradford, [6] with bovine serum albumin used as standard

Optimal conditions for nitrate reductase production: Several factors were studied to determine the optimal conditions for nitrate reductase production from Pseudomonas sp. SH7 isolate and as following:

1. Determination of optimal substrate concentrations: Minimal media broth $(\mathrm{pH}$ 7.0) was prepared with different concentrations of glycerol trinitrate $0.05,(0.1$, $0.15,0.2,0.25,0.3,0.4$ and $0.5 \mathrm{mM}$ ).

2. Determination of nitrate reductase incubation period: Minimal media were inoculated and incubated at $35^{\circ} \mathrm{C}$ for $(1,3,5,7,9,12)$ days).

3. Determination of optimal aeration conditions for nitrate reductase production: Minimal media broth $(\mathrm{pH} 7.0)$ was inoculated with bacterial isolate and incubated at $35^{\circ} \mathrm{C}$ for 3 days under aerobic and anaerobic conditions.

4. Determination of optimal $\mathrm{pH}$ for nitrate reductase production: Minimal media broth with different $\mathrm{pHs}(5,6,7,8,9)$ were inoculated and incubated at $35^{\circ} \mathrm{C}$ for 3 days.

5. Determination of optimal temperature for nitrate reductase production: Pseudomonas sp. SH7 isolate was grown in minimal media broth $(\mathrm{pH} 7.0)$ and incubated at different temperatures $30,35,40,45,50)^{\circ} \mathrm{C}$ for 3 days. Cells from all above factors were harvested by centrifugation at $6000 \mathrm{rpm}$ for $10 \mathrm{~min}$. Cell extracts were prepared by sonication treatment and nitrate reductase assays were performed as described above.

Enzyme purification: All steps for purification of nitrate reductase were carried out at $4{ }^{\circ} \mathrm{C}$, and all buffers contained $2 \%$ glycerol as an enzyme stabilizer.

A. Ammonium sulfate fractionation: The supernatant was fractionated with ammonium sulfate at (40-60) \% saturation, and the precipitate obtained after 
centrifugation at $6000 \mathrm{rpm}$ for $30 \mathrm{~min}$ was suspended in $50 \mathrm{mM}$ phosphate buffer (pH 7.0) and the enzyme activity and protein concentration were measured.

B. DEAE - Cellulose column chromatography: The sample was applied to a DEAE-cellulose (Whatman, DE52) column $(3 \times 25 \mathrm{~cm})$ previously equilibrated with $50 \mathrm{mM}$ phosphate buffer $(\mathrm{pH} 7.0)$. The protein was washed with the same buffer and eluted with a linear salt gradient containing $0-0.3 \mathrm{M} \mathrm{NaCl}$. The enzymatic activity for each fraction was assayed as described above; the curve of enzymatic activity (unit $/ \mathrm{ml}$ ) was plotted against O.D.280 nm. The fractions that revealed significant peak of activity were mixed together.

C. Gel filtration chromatography: The gel (Sephadex G-200) was prepared according to the instruction of the manufacturer. The fractions collected from the DEAE-cellulose column chromatography were applied to a Sephadex G-200 column $(2 \times 90 \mathrm{~cm})$ previously equilibrated with $0.1 \mathrm{M}$ phosphate buffer $(\mathrm{pH} \mathrm{7.5)}$. Elution was performed with the same buffer, the fractions that revealed the protein and enzymatic activity in the same peak were mixed and transferred to a new sterile tube for further study.

SDS-Polyacrylamide electrophoresis: Molecular weight and proteins were determined by denaturing gel electrophoresis in $7.5 \%$ polyacrylamide resolving gels, using a Tris-glycine-SDS buffer system with $\beta$-mercaptoethanol as a reducing agent. Proteins were visualized by staining with Coomassie brilliant blue R-250, there molecular weight were determined by comparison with standard proteins.

Enzyme characterization assays: Some of the characteristics of partially purified nitrate reductase were determined and as the following:

Determination of optimal temperature activity and thermal stability for nitrate reductase: $0.1 \mathrm{ml}$ of partially purified nitrate reductase was added to $0.9 \mathrm{ml}$ of $0.1 \mathrm{M}$ potassium phosphate buffer, containing $0.2 \mathrm{mM}$ glycerin trinitrate as a substrate, was incubated for $15 \mathrm{~min}$. at different temperatures $(25,30,35,40,50,60)^{\circ} \mathrm{C}$ then immediately transferred into an ice bath. Enzymatic activity was measured against the temperature.

While for thermal stability, equal volumes of partially purified nitrate reductase and $0.1 \mathrm{M}$ potassium phosphate buffer solution were incubated in water bath at $(25,30,35$, $40,50,60)^{\circ} \mathrm{C}$ for $15 \mathrm{~min}$., and immediately transferred into an ice bath. Enzymatic activity was measured and the remaining activity (\%) was plotted against the temperature.

Determination of thermal sensitivity for nitrate reductase at $45^{\circ} \mathrm{C}$ : The partially purified nitrate reductase was incubated in a water bath $45^{\circ} \mathrm{C}$ for different times (10, 20, 30, 40, 50, 60) min. and immediately transferred into an ice bath. Enzymatic activity was measured against the temperature.

Determination of $\mathbf{p H}$ effects on nitrate reductase activity and stability: $0.1 \mathrm{ml}$ of Partially purified nitrate reductase was added to $0.9 \mathrm{ml}$ of $0.1 \mathrm{M}$ potassium phosphate buffer, each one of different $\mathrm{pH}(5.5$ - 8.5) containing $0.2 \mathrm{mM}$ glycerin trinitrate as a substrate and nitrate reductase assays were performed.

While for stability equal volumes of partially purified enzyme and $0.1 \mathrm{M}$ potassium phosphate buffer solution with $\mathrm{pH}$ range $(5.5$ - 8.5) were incubated in a water bath at 
$35^{\circ} \mathrm{C}$ for $30 \mathrm{~min}$. then transferred immediately into an ice bath. The enzymatic activity for each one was measured. The remaining activity (\%) for nitrate reductase, optimal $\mathrm{pH}$ for enzyme stability.

Determination of inhibitors effects on nitrate reductase activity: Equal volume of partially purified nitrate reductase were incubated in a water bath with $(0,25,50,100$, $150,200,300) \mu \mathrm{M}$ of sodium azide and $(0,50,100,200,300,400,500,600) \mu \mathrm{M}$ of potassium cyanide at $35^{\circ} \mathrm{C}$ for $10 \mathrm{~min}$., then immediately transferred into an ice bath. The enzymatic activity was measured.

\section{Results and Discussion}

Isolation and identification of microorganisms: Sixty five soil samples and fifteen water samples were collected from different places in which previously explosions were occurred.

Only one isolate was chosen which was $\mathrm{SH} 7$, the highest nitrate and nitrite analysis among them and was identified as Pseudomonas isolate by the criteria of Bergey's Manual of Systematic Bacteriology [4].

Extraction of nitrate reductase: Three of the most known extraction methods were used to determine nitrate reductase activity. Results showed that, Pseudomonas sp. SH7 cells washed with $0.1 \mathrm{M}$ phosphate buffered, treated with sonication have maximal nitrate reductase activity $(1.5 \mathrm{U} / \mathrm{ml})$ compared with SDS treated cells $(0.85$ $\mathrm{U} / \mathrm{ml})$ while the freezing and thawing show very little nitrate reductase activity $(0.2$ $\mathrm{U} / \mathrm{ml})$.

The significant increase in nitrate reductase activity after sonication treatment could be explained depending on the fact that complete lysis of cells would be sufficient to increase nitrate reductase activity since best results were obtained when the cell wall is completely removed and this increas in activity proves that Pseudomonas sp. SH7 isolate having periplasmic nitrate reductase is not membrane-bound nitrate reductase [7].

Recent reports on the isolation of periplasmic nitrate reductase from $D$. desulfuricans described the preparation of cell extracts by sonicated cells suspension for a total of 10 min. using Kubota Isonator Model 20S [8].

Optimum substrate concentrations for nitrate reductase production: Different concentrations of trinitroglycerin were studied $(0.05,0.1,0.15,0.2,0.25,0.3,0.4$, $0.5) \mathrm{mM}$ in which the optimum concentration was $0.25 \mathrm{mM}$ and the specific activity was $0.60 \mathrm{U} / \mathrm{mg}$ protein of Pseudomonas sp. SH7 isolate was shown in Figure (2). Neubauer and Gotz, [9] studied the effect of nitrate on the nitrate reductase activity of S. carnosus. They found that, increasing nitrate from $10 \mathrm{mM}$ to $25 \mathrm{mM}$ lead to increase the specific activity from 1.4 to $2.98 \mathrm{U} / \mathrm{mg}$ proteins.

A recent study found that the optimum substrate concentration for cotton nitrate reductase was $0.1 \mathrm{mM}$ of potassium nitrate and the specific activity at that concentration was $3.2 \mathrm{U} / \mathrm{mg}$ protein and it decreased to $2.5 \mathrm{U} / \mathrm{mg}$ protein when the potassium nitrate was $1.5 \mathrm{M}[10]$. 


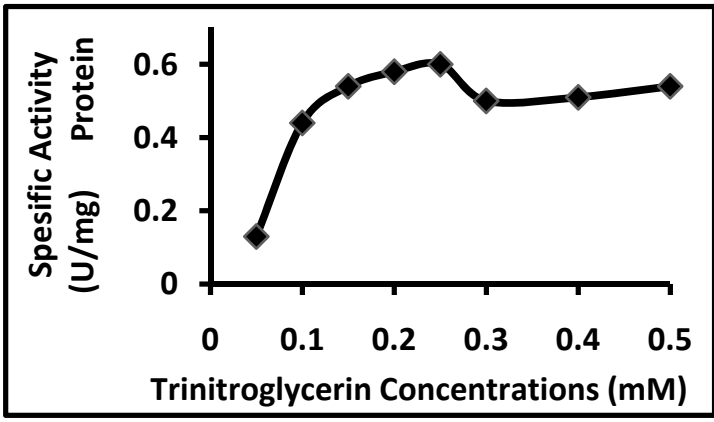

Fig(1): Effect of Trinitroglycerin concentrations on nitrate reductase production from Pseudomonas $\mathrm{SH} 7$

Optimum incubation period for nitrate reductase production: The optimum incubation periods were characterized for the nitrate reductase produced from Pseudomonas SH7 isolate for $(1,3,5,7,9,12)$ days. The maximum production of nitrite occurred when the enzyme was incubated for 3 days in which the specific activity was $0.64 \mathrm{U} / \mathrm{mg}$ protein as shown in Figure (2).

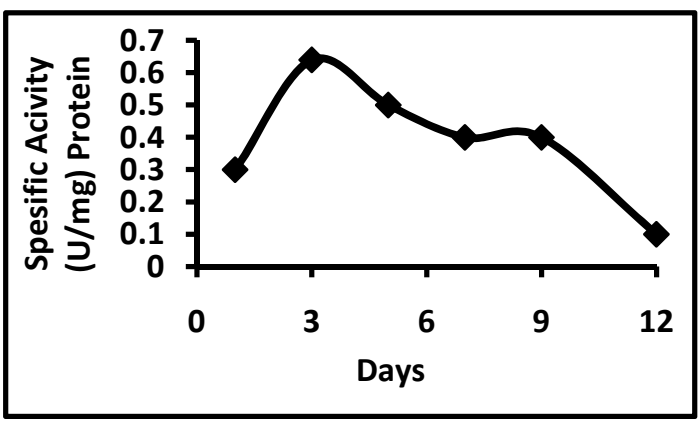

Fig (2): Optimum incubation period for nitrate reductase production from Pseudomonas sp. $\mathrm{SH} 7$

Optimum aeration conditions for nitrate reductase production: Pseudomonas sp. $\mathrm{SH} 7$ isolate was grown in minimal media containing $0.25 \mathrm{mM}$ trinitroglycerin under aerobic and anaerobic conditions. Results showed that the aerobic condition gave a higher specific activity $(0.65 \mathrm{U} / \mathrm{mg}$ protein) than anaerobic condition $(0.5 \mathrm{U} / \mathrm{mg}$ protein), this result was much similar to the results obtained by [19], in which the periplasmic nitrate reductase of $T$. pantotropha was expressed under both aerobic and anaerobic conditions and the specific activity was very low under anoxic condition 0.2 and $0.05 \mathrm{U} / \mathrm{mg}$ protein respectively. In contrast with the other study, a fourfold increase in enzyme activity was observed with anaerobically grown cells of $S$. carnosus. Specific activity under aerobic was 0.15 while under anaerobic was 0.62 $\mathrm{U} / \mathrm{mg}$ protein [9].

Optimum pH for nitrate reductase production: To investigate the effect of the medium $\mathrm{pH}$ on nitrate reductase, Pseudomonas sp. SH7 isolate was grown in minimal media containing $0.25 \mathrm{mM}$ trinitoglycerin with different $\mathrm{pH}$ values $(5,6,7,8$, and 9). The results in Figure (3), showed that the higher production of nitrate reductase was close to optimal $\mathrm{pH}$ of bacterial growth which was 7.0 and the specific activity was 
$0.68 \mathrm{U} / \mathrm{mg}$ protein, while there was low growth at $\mathrm{pH}$ values less than 5.0 and more than 9.0, in which we could suggest the higher production linked to the higher growth of the bacteria, that result was similar to [11] reported that the optimal $\mathrm{pH}$ for nitrate reductase production was 7.1 .

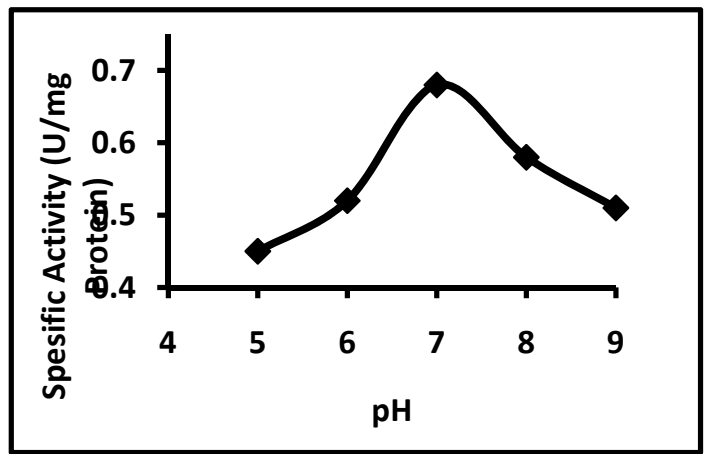

Fig (3): Optimal pH for nitrate reductase production from Pseudomonas sp. SH7

Optimal temperature for nitrate reductase production: The enzyme activity was assayed at various temperatures $(25,30,35,40,45,50)^{\circ} \mathrm{C}$. The optimum temperature for nitrate reductase production was $35^{\circ} \mathrm{C}$ and the specific activity was $0.72 \mathrm{U} / \mathrm{mg}$ protein Figure (4), this result is similar to [12] in which they found that the optimum temperature for growth and production of nitrate reductase was $35^{\circ} \mathrm{C}$.

Other studies on the effect of temperature showed that $P$. denitrificans cannot grow at temperatures above $40^{\circ} \mathrm{C}$ while the optimal temperature for nitrate reduction was found to be about $38^{\circ} \mathrm{C}$ [11], while optimum temperature of thermostable nitrate reductase from the hyperthermal archeaon Pyrobaculum aerophilum was $95^{\circ} \mathrm{C}$ and optimal growth temperature was $100^{\circ} \mathrm{C}$ [13].

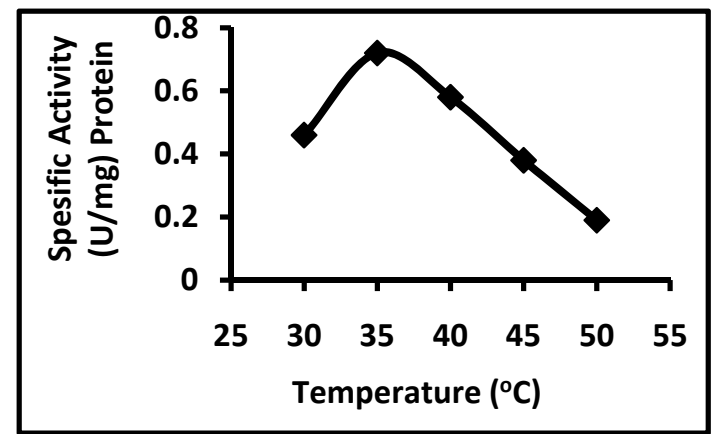

Fig (4): Optimal temperature for nitrate reductase production from Pseudomonas sp. $\mathrm{SH} 7$

Enzyme purification: The purification steps for nitrate reductase from Pseudomonas sp. SH7 are summarized in Table (1).

\section{A. Ammonium Sulfate Precipitation}

In order to concentrate the crude extract of nitrate reductase and remove as much water and some protein molecules as possible, the saturation ratio (40-60) \% was used. It achieved specific activity $4.95 \mathrm{U} / \mathrm{mg}$, with 7.5 purification folds with $54.4 \%$ 
yield. From these results approximately there was duplication in activity within (4060) \% comparing with the crude extract, in addition to an increase in the specific activity. So the ammonium sulfate precipitation is recommended to this particularly stage of purification. Concerning the other studies, those results are similar to those of [14] they found that the specific activity with $60 \%$ ammonium sulfate of dissimilarly nitrate reductase purified from denitrifier $P$. aeruginosa was $24.6 \mathrm{U} / \mathrm{mg}$, while the crude specific activity was $64.8 \mathrm{U} / \mathrm{mg}$ while [15], obtained a specific activity of 0.9 $\mathrm{U} / \mathrm{mg}$ from $E$. coli by using $30 \%$ saturation ratio. Others found that purification of nitrate reductase from $P$. nautica, strain 617 used $40 \%$ sodium sulfate instead of ammonium sulfate. In general, ammonium sulfate is favored in the precipitation step due to its high solubility, availability, being cheap and that it does not damage most enzymes [16].

Table (1): Purification Steps of Nitrate Reductase Produced by Pseudomonas sp. SH7

\begin{tabular}{|c|c|c|c|c|c|c|c|}
\hline $\begin{array}{c}\text { Steps of } \\
\text { Purification }\end{array}$ & $\begin{array}{c}\text { Volume } \\
(\mathrm{ml})\end{array}$ & $\begin{array}{c}\text { Activity } \\
\text { (U/ml) }\end{array}$ & $\begin{array}{c}\text { Protein } \\
\text { Conc. } \\
(\mathrm{mg} / \mathrm{ml})\end{array}$ & $\begin{array}{l}\text { Specific } \\
\text { Activity } \\
\text { (U/mg) }\end{array}$ & $\begin{array}{c}\text { Total } \\
\text { Activity } \\
\text { (U) }\end{array}$ & $\begin{array}{l}\text { Folds of } \\
\text { Purification }\end{array}$ & $\begin{array}{c}\text { Yields } \\
(\%)\end{array}$ \\
\hline $\begin{array}{l}\text { Crude Extract } \\
40-60 \%\end{array}$ & 100 & 1.5 & 2.27 & 0.66 & 150 & 1 & 100 \\
\hline $\begin{array}{l}\text { Ammonium Sulfate } \\
\text { Saturation } \\
\text { Ion Exchange }\end{array}$ & 30 & 2.72 & 0.55 & 4.95 & 81.6 & 7.5 & 54.4 \\
\hline $\begin{array}{l}\text { Chromatography by } \\
\text { DEAE-Cellulose } \\
\text { Gel Filtration }\end{array}$ & 20 & 2.49 & 0.4 & 6.23 & 49.8 & 9.43 & 33.2 \\
\hline $\begin{array}{l}\text { Chromatography } \\
\text { by Sephadex G-200 }\end{array}$ & 10 & 2.24 & 0.19 & 11.79 & 22.4 & 17.86 & 14.9 \\
\hline
\end{tabular}

B. Ion - exchange and gel filtration chromatography: DEAE-cellulose is a weak anion exchanger with excellent flow properities and high capacity for protein of most pI values with a high resolution. The ion exchange functional group is diethylaminoethyl that remains charged and maintains consistently high capacities over the entire working range.

The results in Table (1) showed nitrate reductase purified by anion ion-exchange column chromatography using DEAE-cellulose (3 by $25 \mathrm{~cm}$ ). Figure (5) showed the wash of DEAE-cellulose column had two protein peaks without nitrate reductase activity, while Figure (6), showed that there was one peak for protein and one peak for nitrate reductase activity coincidence with each other in the elution fraction. Therefore, it could be concluded that nitrate reductase has been bounded onto the matrix of the exchanger, those protein fractions were washed out. Then the elution was run using the same buffer with linear salt gradient $0 \mathrm{M}$ to $0.3 \mathrm{M} \mathrm{NaCl}(\mathrm{pH} 7.0)$ which could detect as in. Then the fractions were collected together giving specific activity of $6.23 \mathrm{U} / \mathrm{mg}$ with 9.43 folds of purification and $33.2 \%$ yield. 


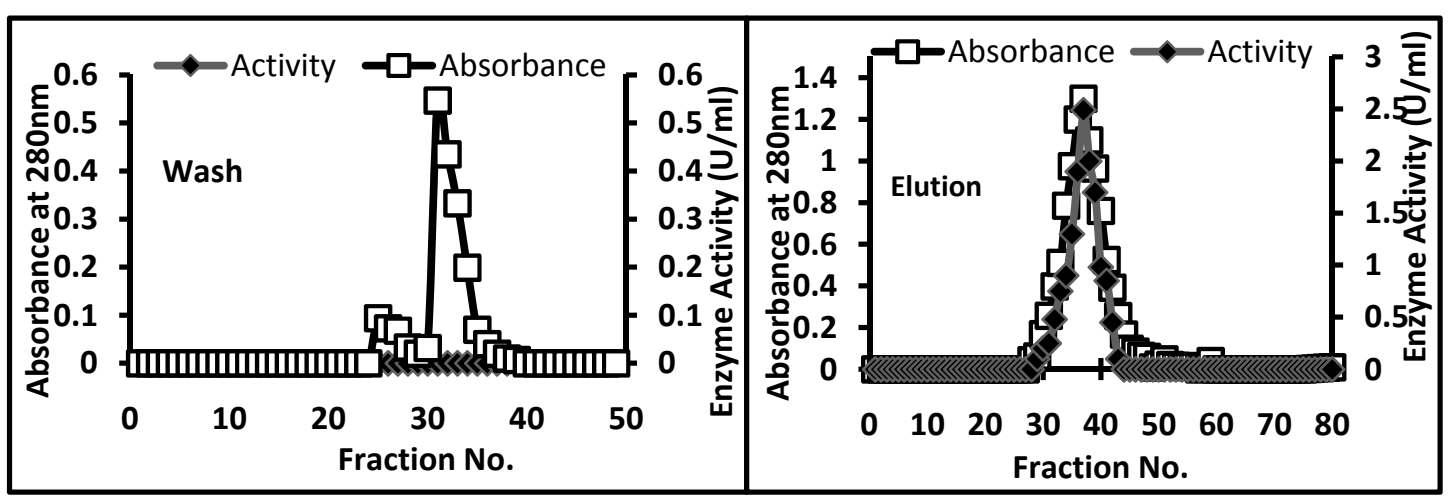

Fig (5): DEAE-Cellulose ion-exchange chromatography column $(3 \times 25 \mathrm{~cm})$ equilibrated with $0.1 \mathrm{M}$ phosphate buffer $\mathrm{pH}$ 7.2, Fraction volume: $3 \mathrm{ml} /$ tube
Fig (6): DEAE-Cellulose ion-exchange chromatography column $(3 \times 25 \mathrm{~cm})$, enzyme recovered with linear salt gradient $0-0.3 \mathrm{M} \mathrm{NaCl}$

The fraction from DEAE-cellulose column chromatography was applied to a Sephadex G200 column $(2 \mathrm{~mm} \times 90 \mathrm{~cm})$ previously equilibrated with $0.1 \mathrm{M}$ phosphate buffer . Gel filtration step for partially purified nitrate reductase was done, Figure (7), showed that there are two peaks, one peak for protein without any enzyme activity, while other peak for the enzyme in the eluted fraction from $27^{\text {th }}$ to $40^{\text {th }}$ with specific activity $11.79 \mathrm{U} / \mathrm{mg}$, fold of purification 17.86 and yield $14.9 \%$, which are considered as a good result when compared with other studies.

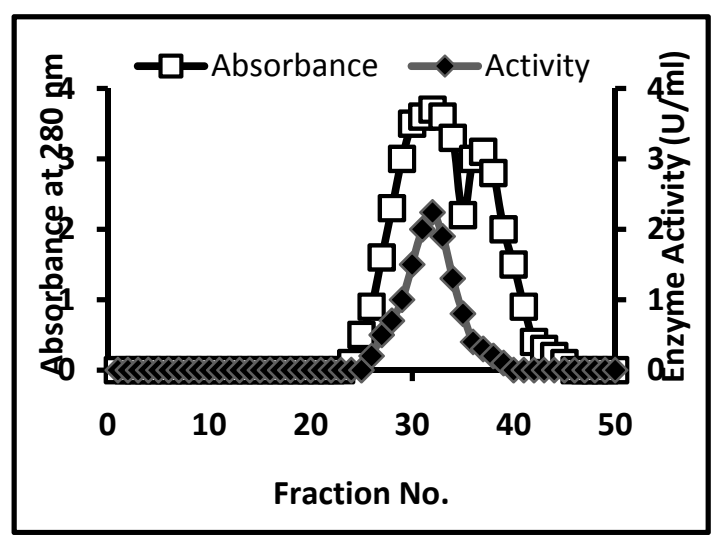

Fig (7): Gel filtration chromatography by sephadex G200 column $(2 \times 90 \mathrm{~cm})$ equilibrated with $0.1 \mathrm{M}$ phosphate buffer pH 7.0, fraction volume: $3 \mathrm{ml} /$ tube.

[17] purified nitrate reductase from $P$. fluorescence and $P$. putida by DEAEcellulose chromatography followed by and Q-Sepharose, showed specific activity of 0.35 and $0.33 \mathrm{U} / \mathrm{mg}$ with a yield of 71 and $33 \%$ respectively. [15] purified nitrate reductase from E. coil by alkali-acetone treatment followed by Sephadex G200 filtration and Bio-gel A15 filtration to get enzyme with specific activity of $15.8 \mathrm{U} / \mathrm{mg}$ and purification folds 52.5 with yield $1.6 \%$, while Burke and Lascelles, [18]; could purify nitrate reductase enzyme by Bio-gel A1.5m with specific activity $7.7 \mathrm{U} / \mathrm{mg}$ and yield $71 \%$ followed by ECTEOLA-cellulose, with specific activity of $12.4 \mathrm{U} / \mathrm{mg}$ and yield $33 \%$. 
Furthermore, nitrate reductase purified from A. eutrophus H16 by Alkyl Superose and Mono Superose with specific activity 2.4 and $32.9 \mathrm{U} / \mathrm{ml}$ and yield 26 and $9 \%$ respectively [19].

Determination of enzyme purity: The purified enzyme was electrophoresed under denaturing conditions using 7.5\% SDS-PAGE in the presence of $\beta$-mercaptoethanol. Single protein band appear in the gel, when stained by Coomassie blue R250 Figure (8), indicating that nitrate reductase purified till homogeneity. The molecular weight of nitrate reductase was about $115 \mathrm{kD}$ when compared with the molecular weight of standard proteins as shown in Figure (9). This value is similar to those reported for other nitrate reductase purified from S. aureus, P. aeroginosa and P. isachenkovii which had a molecular weight 112,115 and $118 \mathrm{kD}$ respectively $[7,14,18]$.
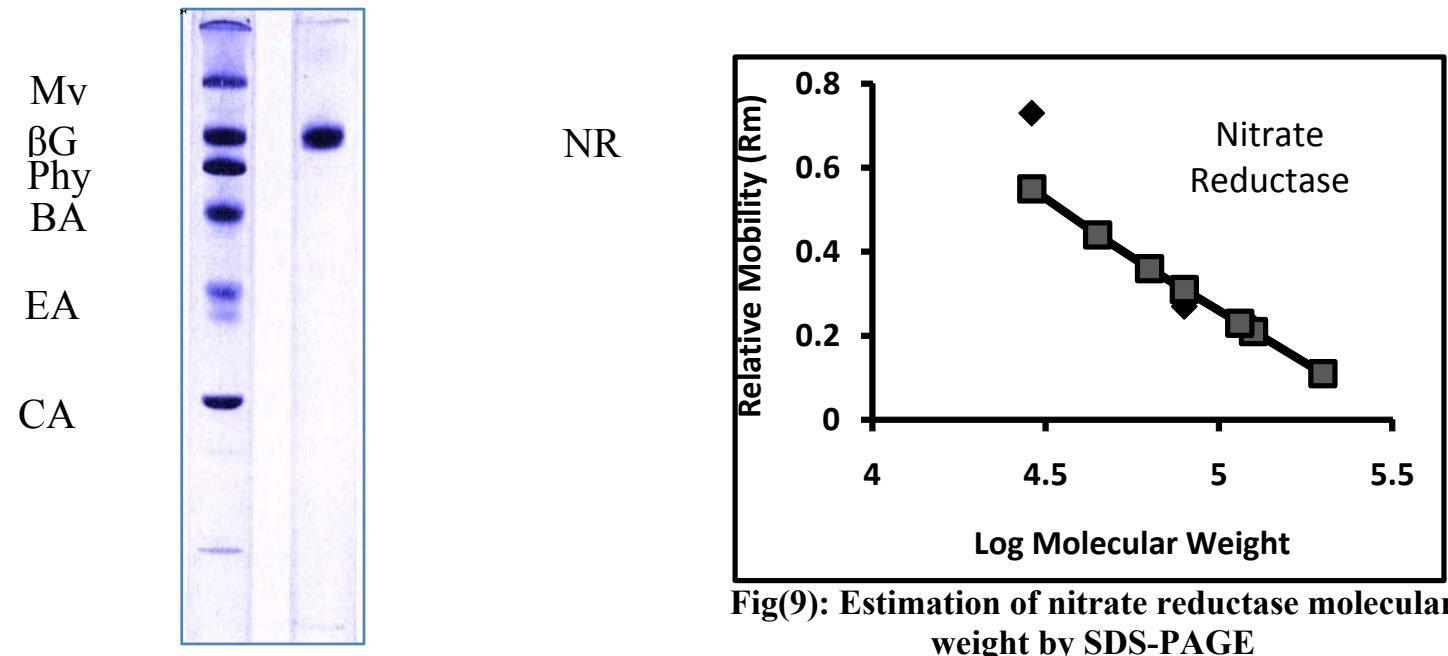

Fig(9): Estimation of nitrate reductase molecular weight by SDS-PAGE

Fig(8): SDS gel electrophoresis of nitrate reductase The gel on the right is Nitrate Reductse (NR) after gel filtration. The gel on the left is standard protein (from top): Myosin (My) (205KD), $\beta$-Galactosidase (116KD), Phosphorylase (Phy) (97KD), Bovine Albumin (BA) (66KD), Egg Albumin (EA) (45KD), and Carbonic Anhydrase (CA) (29KD)

Optimum $\mathrm{pH}$ on nitrate reductase activity: The effect of $\mathrm{pH}$ on purified nitrate reductase from Pseudomonas sp. SH7 was studied in $\mathrm{pH}$ range from 5.5-8, as shown in figure 10. The optimum $\mathrm{pH}$ was observed at values between (6.5-7.5), but the enzyme was active at $\mathrm{pH} 7.0$, the activity was $2.9 \mathrm{U} / \mathrm{ml}$. The active sites on enzyme are frequently composed of ionizable groups that must be in the proper ionic form in order to maintain the conformation of the active sites or change the configuration of the enzyme itself [20], which could be explain the decrease in activity at extreme values of acidity $(5.5,6.5)$ and alkalinity $(8)$.

Concerning the results of the other studies, the optimal $\mathrm{pH}$ for the nitrate reductase activity produced by Haloferax mediterranei was 7.2. While others found that the optimum $\mathrm{pH}$ for nitrate reductase purified from Haloarcula marismortui was 9.2. [21]. 


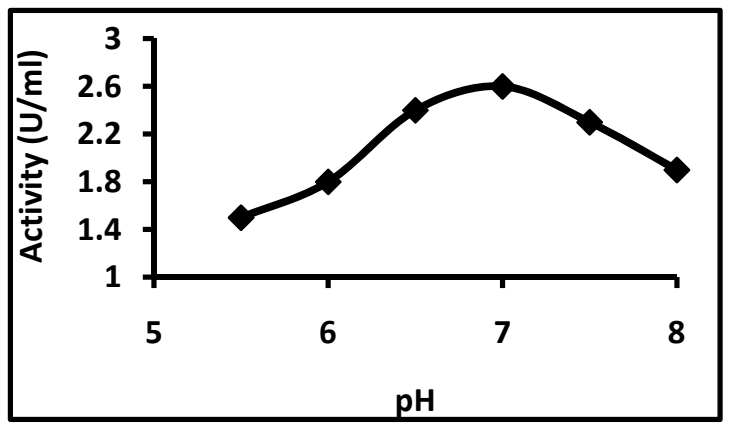

Fig(10): Optimal pH for nitrate reductase activity purified from Pseudomonas sp. SH7

Effect of pH on nitrate reductase stability: In order to determine the optimal $\mathrm{pH}$ for nitrate reductase stability, the enzyme was incubated in a buffer solution with a $\mathrm{pH}$ range from 5.5 to 8 at $35^{\circ} \mathrm{C}$ for $30 \mathrm{~min}$.

Best stability was observed at $\mathrm{pH} 7.0$ were more than $95 \%$ of the activity remained as showen in Figure (11).

Studies on $P$. denitrificans nitrate reductase showed that the enzyme was stable in the pH from 6 to 9 and more than $80 \%$ of the activity remained at pH 7.0 while enzymatic activity eliminated at $\mathrm{pH} 3.0$ [11]. [8], stated that $D$. desulfuricans nitrate reductase had high stability at $\mathrm{pH} 6.5$.

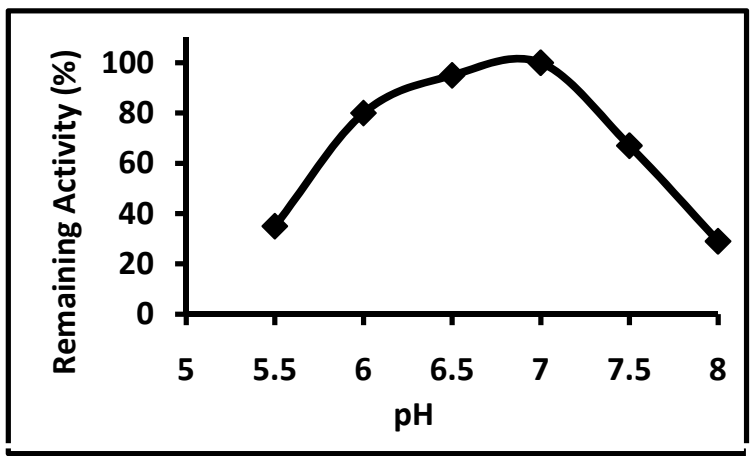

Fig(11): Nitrate reductase stability at different pH values

Effect of temperature on nitrate reductase activity: The maximum activity of nitrate reductase was showed at $35^{\circ} \mathrm{C}$, as in Figure (12), and decreasing in enzyme activity was observed whenever temperature increased more than $35^{\circ} \mathrm{C}$.

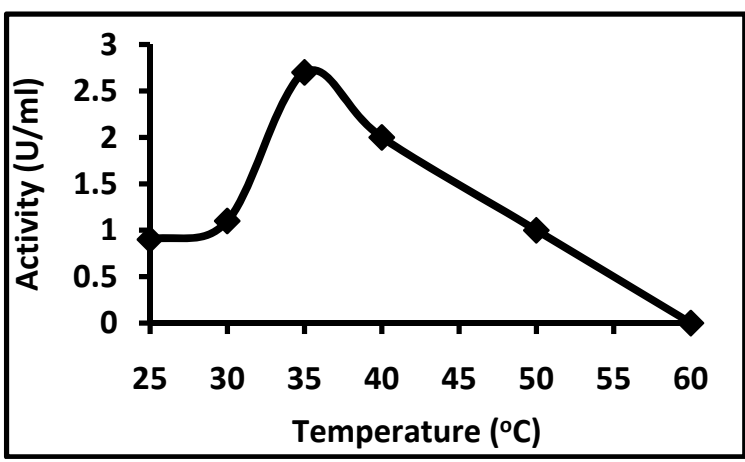

Fig(12): Optimal temperature for nitrate reductase activity purified from Pseudomonas sp. SH7 
The maximal activity of thermostable nitrate reductase from the hyperthermophilic archaeon Pyrobaculum aerophilum was above $95^{\circ} \mathrm{C}$ [15], while the optimal activity temperatures for P. ambigue, E. coli DH5 $\alpha$ and V. harveni KCTC 2720 were 55, 30 and $30^{\circ} \mathrm{C}$ respectively [22]. Other study found that the optimum activity of nitrate reductase isolated from $H$. mediterranei was $70^{\circ} \mathrm{C}$ [21].

Effect of temperature on nitrate reductase stability: The stability of nitrate reductase from Pseudomonas sp. SH7 was examined by incubation enzyme at various temperature ranges from $30^{\circ} \mathrm{C}$ to $80^{\circ} \mathrm{C}$ for $15 \mathrm{~min}$.

The results in Figure (13), revealed that the enzyme was active up to $50^{\circ} \mathrm{C}$, maximal enzyme activity was observed at $(30-40)^{\circ} \mathrm{C}$, the activity declined when incubated at higher temperature, although $80 \%$ of the activity remained at $50^{\circ} \mathrm{C}$. The enzyme activity was completely suppressed at $80^{\circ} \mathrm{C}$ for $15 \mathrm{~min}$.

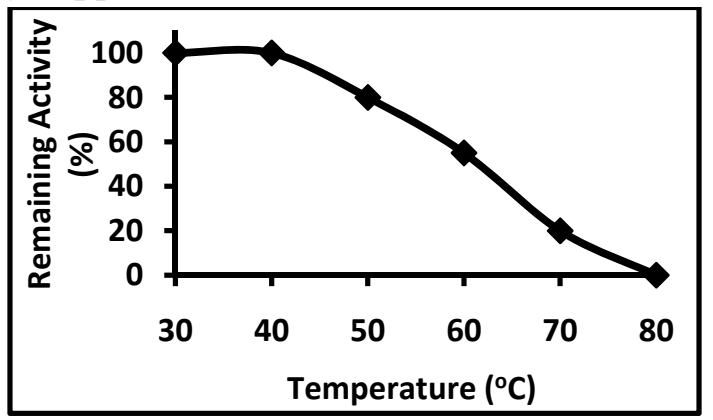

Fig(13): The effect of temperature on nitrate reductase stability purified from Pseudomonas sp. $\mathrm{SH} 7$

To determine the stability of the enzyme, purified nitrate reductase was incubated at $45^{\circ} \mathrm{C}$. Decrease in enzyme activity was observed when the enzyme was incubated more than 20 min. and less than $20 \%$ of the activity was remained after incubation for 60 min., result in Figure (14).

[23] found that the optimal temperature for activity of nitrate reductase from $B$. frigilis was $35^{\circ} \mathrm{C}$ and this enzyme was heat sensitive since it lost more than $60 \%$ of the activity after incubation at $42^{\circ} \mathrm{C}$ for $20 \mathrm{~min}$., while nitrate reductase from denitrifier $P$. aeruginosa was heat stable since it could be heated for $10 \mathrm{~min}$. at 65 to $70^{\circ} \mathrm{C}$, or for more than $90 \mathrm{~min}$. at $50^{\circ} \mathrm{C}$, without loss in activity [14].

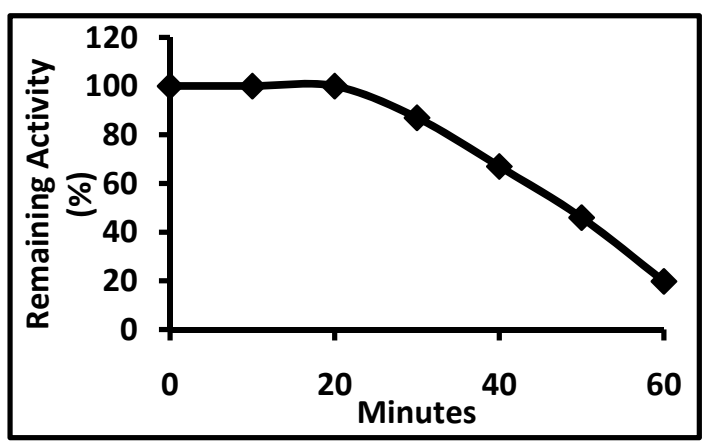

Fig(14): Stability of nitrate reductase at $45^{\circ} \mathrm{C}$ for different time values purified from Pseudomonas sp. SH7 
Effect of inhibitors on nitrate reductase activity: Sodium azide and potassium cyanide are known as inhibitors of nitrate reductase. The effects of different concentrations of each inhibitor were investigated.

Nitrate reductase from Pseudomonas sp. SH7 treated with $(50,100,150,200) \mu \mathrm{M}$ sodium azide showed inhibition in activity by $(11,24,46,76) \%$ respectively, whereas $(100,200,300,400,500) \mu \mathrm{M}$ potassium cyanide treatment inhibited the activity by $(35,58,75,86,91) \%$ respectively, as in Figure $(15,16)$.

Cyanide and Azide exhibited a pattern of inhibition of the activities of nitrate reductase; this data suggests that the metal components may be functioning in nitrate reductase. [7], found that nitrate reductase purified from $P$. isachenkovii was very sensitive to low concentrations of cyanide $(40 \mu \mathrm{M})$ and azide $(20 \mu \mathrm{M})$, this inhibition because of the presence of a metal atom in the active site.

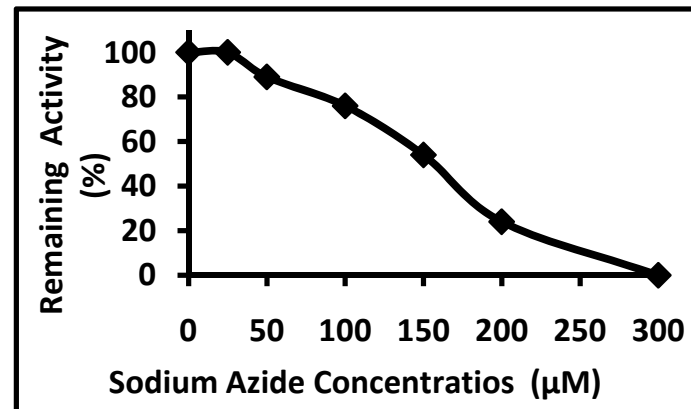

Fig (15): The effect of sodium azide concentrations $(0-300 \mu \mathrm{M})$ on nitrate reductase activity

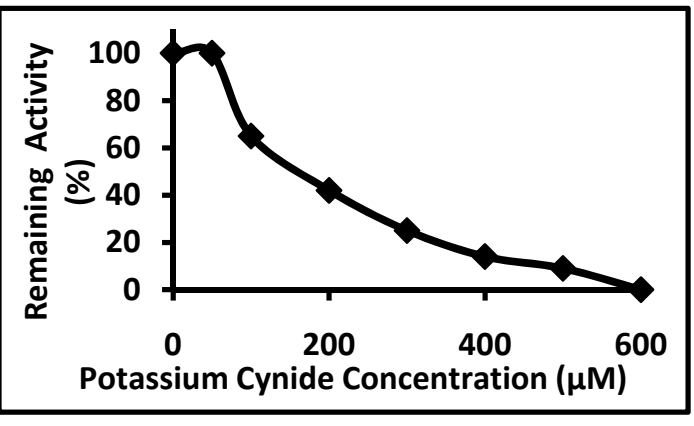

Fig(16): The effect of potassium cynide concentrations $(0-600 \mu \mathrm{M})$ on nitrate reductase activity

\section{References}

1. Trott, S.; Nishino, S.F.; Hawari, J. and Spain, J.C. (2003). Biodegradation of the nitramine explosive CL-20. Appl. Environ. Microbiol., 69(3): 1871 - 1874.

2. Moreno - Vivian, C.; Cabello, P.; Martinez - Luque, M.; Blasco, R. and Castillo, F. (1999). Prokaryotic Nitrate Reductase: Molecular Properties and Functional Distinction among Bacterial Nitrate Reductase. J. Bacteriol., 181(21): 6573 - 6584.

3. Bru, D.; Sarr, A. and Philippot, L. (2005). Relative Abundances of Proteobacterial Membrane-Bound and Periplasmic Nitrate Reductases in Selected Environments. Appl. Environ. Microbiol. 73(18): 5971-5974.

4. Krieg, N. R., and Holt, J.G. (ed.). (1984). Bergey's Manual of Systematic Bacteriology $1^{\text {st }}$ Edition. Vol. (1). Williams \& Wilkins, Baltimore, MD

5. Smarrelli, J.R. and Campbell, W.H. (1983). Enzymatic assay of nitrate reductase (EC 1.6.6.1). Biochimica. Biophysica. Acta., 742: 435-445.

6. Bradford, M. (1976). A rapid and sensitive method for the quantitation of microgram quantities of protein utilizing the principle of protein - dye binding. Annu. Biochem., 72: $248-254$.

7. Antipov, A.N.; Lyalikova, N.N.; Khiznjak, T.V. and Lvov, N.P. (1999). Some properties of dissimilatory nitrate reductases lacking molybedenum and molybedenum cofactor. Biochem. (Moscow), 64(5): 483 - 487. 
8. Gonzalez, P.J.; Rivas, M.G.; Brondino, R.D.; Bursakov, S.A.; Moura, I. and Moura, J.J.G. (2006). EPR and redox properties of periplasmic nitrate reductase from Desulfovibrio desulfuricans ATCC 27774. J. Biol. Inorg. Chem., 11(5): 609 - 616.

9. Neubauer, H. and Gotz, F. (1999). Physiology and interaction of nitrate and nitrite reduction in Staphylococcus carnosus. J. Bacteriol., 178(7): 2005 - 2009.

10. Kouadio, J.Y.; Kouakou, H.T.; Kone, M.; Zouzou, M. and Anno, P.A. (2007). Optimum conditions for cotton nitrate reductase extraction and activity measurement. Afr. J. Biotechnol., 6(7): 923 - 928.

11. Wang, J.H.; Baltzis. B.C. and Lewandowski, G.A. (2004). Fundamental denitrification kinetic studies with Pseudomonas denirtificans. Biotechnol. Bioengineering, 47(1): 26 -41 .

12. Marietou, A.; Richardson, D.; Cole, J. and Mohan, S. (2005). Nitrate reduction by Desulfovibrio desulfuricans: A periplasmic nitrate reductase system that lacks Nap B, but includes a unique tetraheme c-type cytochrom, Nap M. FEMS Microbiol. Lett., 248(2): $217-225$.

13. Afshar, S.; Johnson, E.; DeVries, S. and Schroder, I. (2001). Properties of a thermostable nitrate reductase from hyperthermophilic archaeon Pyrobaculum aerophilum. J. Bacteriol., 183(19): 5491 - 5495.

14. Carlson, C.A.; Ferguson, L.P. and Ingraham, J.L. (1982). Proprieties of dissimilatory nitrate reductase purified from the denitrifier Pseudomonas aeruginosa. J. Bacteriol., 15(1): $162-171$.

15. Forget, P. (1994). The Bacterial Nitrate Reductase. Eur. J. Biochem., 62: 325 - 332.

16. Bonin, P.; Bertrand, J.C.; Giordano, G. and Gilewicz, M. (1987). Specific sodium dependence of a nitrate reduction in marine bacterium. FEMS Microbiol. Lett., 48(12): 5 - 9 .

17. Blehert, D.S.; Fox, B.G. and Chambliss G.H. (1999). Cloning and sequence analysis of two Pseudomonas flavoprotein xenobiotic reductase. J. Bacteriol., 181: 6254 6263.Burke, K.A. and Lascelles, J. (1999). Partial purification and some properties of Staphylococcus aureus cytoplasmic nitrate reductase. J. Bacteriol., 149(1): 120 - 125.

18. Burke, K.A. and Lascelles, J. (1999). Partial purification and some properties of Staphylococcus aureus cytoplasmic nitrate reductase. J. Bacteriol., 149(1): 120 - 125.

19. Siddiqui, R.A.; Warnecke-Eberz, V.; Hengsberger, A.; Schneider, B.; Kostka, S. and Friedrich, B. (1993). Structure and function of a periplasmic nitrate reductase in Alcaligenes eutropus H16. J. Bacteriol., 175(18): 5867 - 5876.

20. Segel, J.J. (1976). Biochemical Calculation. $2^{\text {nd }}$ edition. John Wiley and Sons. New York.

21. Liedo, B.; Martinez-Espinosa, R.M.; Marhuenda-Egea, F.C. and Bonete, J. (2004). Respiratory nitrate reductase from haloarchaeon Haloferax mediterranei: biochemical and genetic analysis. Biochem. Biophys. Acta., 1674(1): 50 - 59.

22. . Kwak, Y.H.; Lee, D.S. and Kim, H.B. (2003). Vibrio harveyi nitroreductase is also a chromate reductase. Appl. Environ. Microbiol., 69(8): 4390 - 4395.

23. Kinouchi, T. and Ohnishi, Y. (1983). Purification and characterization of 1Nitropyrene nitroreductase from Bacteriods fragilis. Appl. Environ. Micrbiol., 46(3): $596-604$. 